\title{
A Rush of Blood to the Head: Temporal Dimensions of Retrenchment, Environment and Turnaround Performance
}

\begin{abstract}
In this work we test the general assumption in the turnaround literature that time is critical for firm survival, especially during the retrenchment stage. We study three time dimensions of change at this stage: timing, speed and rhythm. Drawing on the downward spiral and threat-rigidity perspectives, we posit that the positive impact these time dimensions have on turnaround performance is highly contingent on two types of environment. Our findings, based on a sample of 263 declining US firms over a 26-year period (1983-2009), demonstrate that an early timing of retrenchment has a positive impact on performance when the environment is munificent. On the contrary, an early timing has a negative impact when the environment is dynamic. We also note that a fast pace of retrenchment positively impacts firm performance in dynamic environments. Finally, we find that declining firms display better performances when following an irregular rhythm of retrenchment, both in highly munificent and highly dynamic environments. Our results indicate that, in general, declining firm performance improves with time-aggressive retrenchment actions in both types of environment. We discuss the contribution of our research to the turnaround literature, and the downward spiral and threat-rigidity perspectives.
\end{abstract}


“(Turnaround) leaders need a fine sense of timing”- Bibeault (1982)

\section{Introduction}

The literature has unanimously acknowledged that time is critical to the survival of declining firms (Arogyaswamy et al., 1995; Hambrick, 1985; Pearce II and Robbins, 1993).

Consequently, "time is of the essence to turnarounds" (Slatter et al., 2006: p. 9; Whitney, 1987: p. 120). Time is especially important for retrenchment. Retrenchment denotes both the first stage in a turnaround, and the actions carried out during this stage (Pearce II and Robbins, 1993; Robbins and Pearce, 1992). These actions involve the deliberate reduction of costs and assets (Pearce II and Robbins, 1993; Trahms et al., 2013). The role retrenchment plays remains highly controversial because empirical data has been inconsistent (Barker and Mone, 1994; Pearce II and Robbins, 1993). In an effort to shed light on these inconsistencies, the literature has examined factors influencing the effect of retrenchment on turnaround performance (Lim et al., 2013; Ndofor et al., 2013). Time is one of these factors, perhaps the most vital (Tangpong et al., 2015).

Time is a complex concept encompassing a range of dimensions: timing, cycle, speed, rhythm and frequency, among others (Ancona et al., 2001a; Huy, 2001). The decline literature has clearly recognized two of those dimensions, timing and speed, as being essential to a successful turnaround (Arogyaswamy et al., 1995; Bibeault, 1982; Grinyer et al., 1992; Pearce II and Robbins, 1993). Timing is defined as the moment an event happens or is planned to happen (Huy, 2001). Speed is defined as the amount of time a firm requires to achieve a target (Casillas and Acedo, 2013; Chen and Hambrick, 1995). A widespread assumption and critical pillar to the retrenchment literature is the notion that an early initiation (i.e., timing) and a fast pace (i.e. ,speed) of retrenchment enhance the chances of survival (Arogyaswamy et al., 1995; Bibeault, 1982; Pearce II and Robbins, 1993). 
The downward spiral perspective (Hambrick and D'Aveni, 1992, 1988) suggests that because decline is a protracted process which erodes slack resources, troubled firms should act early and fast to avoid collapse. However, we have very limited evidence of this being the case for the timing of retrenchment (Tangpong et al., 2015), and no evidence for the speed of retrenchment. A third important time dimension for retrenchment used in the change literature is rhythm (Klarner and Raisch, 2013; Vermeulen and Barkema, 2002). Rhythm is defined as the pattern of variability in the intensity and frequency of activity (Huy, 2001). An irregular rhythm of retrenchment implies firms execute actions unevenly and with different degrees of intensity over the retrenchment period. The literature has made no mention of exactly how central rhythm is to turnaround success or retrenchment. All in all, the study of time and retrenchment represents a critical but under-researched area in the turnaround literature (Datta et al., 2010; Pearce II and Robbins, 1993; Tangpong et al., 2015).

The environment, a concept rooted in the downward spiral (Hambrick and D'Aveni, 1988) and threat-rigidity perspectives (Staw et al., 1981), is yet another critical factor influencing turnaround outcomes. These two seminal perspectives posit that a munificent environment, defined as the degree to which the general business environment can support a sustained rate of growth (Aragon-Correa and Sharma, 2003; Miller et al., 1982), can act as a buffer by providing slack resources (Hambrick and D'Aveni, 1988; Staw et al., 1981). These perspectives also argue that high dynamism, representing the rate of change and the degree of unpredictability and turbulence in the environment (Dess and Beard, 1984; Farjoun, 2010), can act as a trigger to firm demise (Hambrick and D'Aveni, 1988; Staw et al., 1981). Given its importance to declining firm performance, the environment can be expected to influence the impact of temporal dimensions of retrenchment on turnaround performance. In other words, the impact of early, fast or irregular retrenchment on performance will be moderated 
by whether the environment is munificent or dynamic. Hence, we put forth two research questions: a) How do early timing, a fast pace and an irregular rhythm of retrenchment impact turnaround performance in munificent environments which provide firms with extra resources? And, b) How do early timing, a fast pace and an irregular rhythm of retrenchment impact turnaround performance in dynamic environments, characterized by uncertainty and unpredictability? The focus of our research is, then, to determine just how time-aggressive declining firms should be in each of these two types of environment. In studying these questions, our main aim is to respond to the call for more empirical research on the critical topic of the relationship between time and turnaround success (Tangpong et al., 2015). Secondly, we mean to validate the influence environment exerts on time and turnaround performance as suggested by the downward spiral and threat-rigidity perspectives. Figure 1 shows our conceptual model.

INSERT FIGURE 1 ABOUT HERE

We select a panel of US manufacturing firms with over 500 employees in decline between 1983 and 2009 (US SIC 2000-4000) which implemented retrenchment measures. To test our hypotheses, we choose Tobin's Q as our dependent variable, a proxy for performance previously used in the turnaround literature (Latham and Braun, 2009; Morrow et al., 2004; Norman et al., 2012) and the timing/speed literature (Pacheco-de-Almeida et al., 2015, 2010). We use the Feasible Generalized Least Squares (FGLS) approach (Wooldridge, 2009) to estimate the results for our panel. FGLS yields unbiased, consistent, efficient, asymptotically normal estimators (Kariya and Kurata, 2004).

Our study contributes to the turnaround literature in several ways. First, by including in our analysis the speed and rhythm of retrenchment, we provide a temporal framework for 
analyzing retrenchment decisions beyond timing (Tangpong et al., 2015). Second, we expand upon the controversial extant literature of factors influencing the effect of retrenchment on turnaround performance (Lim et al., 2013; Trahms et al., 2013) by including key temporal dimensions and environments. We find that troubled firms should in general be timeaggressive in both types of environment. Nevertheless, they should be more time-aggressive in munificent contexts and less so in dynamic contexts. Third, we also contribute by extending the downward spiral and threat-rigidity perspectives environmental focus to also contain the temporal dimensions of retrenchment.

In the next section, we define the three temporal dimensions of retrenchment. Next, we briefly present and describe the downward spiral and threat-rigidity perspectives used to support our hypotheses. Then, we develop our hypotheses, which posit the direct effects of the temporal dimensions of retrenchment on turnaround performance, and the moderating effects of the type of environment on the relationship between the temporal dimensions of retrenchment and turnaround performance. After that, we describe our research methods and present the results of the empirical analysis. Finally, we outline the study's main contributions and implications for theory and practice and discuss its limitations and future research directions.

\section{Conceptual background}

\section{Time dimensions of a turnaround}

The study of time has recently sparked a surge in change management research (Hawk et al., 2013; Klarner and Raisch, 2013; Pacheco-de-Almeida et al., 2015). Time has a greater impact on some change situations than on others (Huy, 2001). In the case of turnarounds, the traditional literature has consistently argued and assumed that time is critical (Arogyaswamy 
et al., 1995; Bibeault, 1982; Pearce II and Robbins, 1993) because it can itself influence the outcomes of a turnaround (Zimmerman, 1991).If carried out non-temporally it may result in the collapse of the firm (Tangpong et al., 2015). Moreover, time is one of the two essential ingredients, together with money, in a successful turnaround (Zimmerman, 1991).

There are several interesting dimensions in time research (Ancona et al., 2001b; Huy, 2001). Most authors have focused on three dimensions: timing, speed and rhythm of change (Amis et al., 2004; Gersick, 1994; Huy, 2001; Klarner and Raisch, 2013). Timing is defined as the moment an event is initiated or is planned to be initiated (Huy, 2001). Events are discrete, exceptional, discontinuous "happenings" which diverge from the organization's routine features (Morgeson, Mitchell, \& Liu, 2015: p. 519). Retrenchment is the focal event of our research $^{1}$ and constitutes a non-routine, exceptional event. The timing of retrenchment indicates how early retrenchment starts.

Speed is defined as the amount of time that a firm requires to achieve a target (Casillas and Acedo, 2013; Chen and Hambrick, 1995). Speed is used to quantify the amount of time employed in a specific action, such as the speed of response to a competitor (Smith et al., 1991), or in a specific process, for instance the speed of strategic renewal (Volberda et al., 2001) or the speed of internationalization (Vermeulen and Barkema, 2002). The turnaround literature has used this process-centered perspective to define the speed of retrenchment as "the longevity of the retrenchment process" (Pearce II and Robbins, 1993: p. 633). Declining firms pursue a fast or a slow pace of retrenchment based on whether retrenchment is executed in a short or a long period of time from the onset of the turnaround.

Rhythm of change is defined as the pattern of variability in the intensity and frequency of activity (Huy, 2001). A firm following an irregular rhythm of retrenchment carries out

\footnotetext{
${ }^{1}$ In the situation of analysis there are actually two salient events: decline and retrenchment. Morgeson et al. (2015) discuss this situation when they describe how events can form chains of events that affect organizations across time. In our case an initial event (decline) prompts retrenchment: the focal event of our study.
} 
retrenchment measures unevenly and with a different intensity over the retrenchment period (Huy, 2001; Vermeulen and Barkema, 2002). Conversely, firms pacing regularly distribute the intensity of retrenchment evenly over the retrenchment period (Huy, 2001; Vermeulen and Barkema, 2002). Table 1 below summarizes the temporal dimensions of retrenchment.

\section{INSERT TABLE 1 ABOUT HERE}

Also, to help the reader better understand the concepts in our research, Figure 2 depicts the possible combinations of timing, speed and rhythm of retrenchment. The figure includes eight sample firms (firms A, B, C, D, E, F, G and H) representing the eight possible combinations.

\section{INSERT FIGURE 2 ABOUT HERE}

We have organized Figure 2 by dividing it into two halves based on the timing of retrenchment. The top half corresponds to firms retrenching early (firms A, B, C and D), while the bottom half corresponds to firms retrenching late (firms E, F, G and H). Each half includes the four possible combinations of speed and rhythm of retrenchment. These four combinations are slow/regular (firms A and E), fast/regular (firms B and F), slow/irregular (firms C and G), fast/irregular (firms D and H). In our depiction, firms engage in retrenchment actions over time. The bumps in the illustrations represent these actions. The retrenchment period is the time lapse between the first retrenchment action (the first bump) and the last retrenchment action (the last bump).

The top half and the bottom half of Figure 2 are almost identical. The difference is that, in the bottom half, the bumps are initiated later, indicating a late timing of retrenchment (firms $\mathrm{E}$ to 
H). In contrast, in the top half the bumps appear earlier to represent an earlier timing of retrenchment (firms A to D). Next, we describe the speed and rhythm of retrenchment by focusing our description on the top half of Figure 2 (firms A to D). This description also applies to the bottom half (firms $\mathrm{E}$ to $\mathrm{H})^{2}$. In regards to speed, the retrenchment period of firms B and D is shorter than that of firms A and C. Firms B and D complete retrenchment in a shorter time lapse. Therefore, the retrenchment pace of firms B and D is faster than that of firms A and C. Next, we illustrate the rhythm of retrenchment. The height of the bump marks the intensity of the retrenchment action. The retrenchment actions by firms A and B are evenly distributed throughout the retrenchment period, and the intensity of those actions is homogeneous. Thus, firms A and B display a regular pace of retrenchment. Conversely, retrenchment actions by firms $\mathrm{C}$ and $\mathrm{D}$ are scattered unevenly throughout the retrenchment period, and the intensity of those actions varies widely. As a result, firms C and D display an irregular pace of retrenchment.

\section{Theory and Hypotheses}

\section{Theoretical background}

We use two perspectives to underpin our arguments regarding the impact of the temporal dimensions of retrenchment and environment on turnaround success: the downward spiral (Hambrick and D'Aveni, 1992, 1988) and threat-rigidity perspectives (Staw et al., 1981). The downward spiral perspective focuses on the process of decline and its effects on the firm. The threat-rigidity perspective centers on firms' response to decline. Hence, the two frameworks complement each other.

\footnotetext{
${ }^{2}$ Each firm in the top half is identical in terms of the speed and rhythm of retrenchment to another firm in the bottom half. Thus, firms A and $\mathrm{E}$ follow an identical speed (slow) and rhythm of retrenchment (regular). Firm B is identical to firm F (fast/regular), firm C to firm G (slow/irregular) and firm D to firm H (fast/irregular). These pairs of firms differ, however, in their timing of retrenchment (early/late).
} 
The downward spiral perspective posits that firm resources play a fundamental role in the process of decline. First, the perspective describes decline as a protracted process of resource erosion (Hambrick and D'Aveni, 1988). Declining firms are more vulnerable to decline under conditions of scant organizational slack (Hambrick and D'Aveni, 1988). They end up failing when poor performance erodes these resources (Levinthal, 1991). Erosion also negatively affects declining firms' capacity to carry out a successful turnaround (Barker III and Duhaime, 1997). Second, the environment plays a critical function in their survival given its role as a resource facilitator (Hambrick and D'Aveni, 1988). As long as the environment remains munificent, declining firms manage to survive despite resource erosion. In the final stages of the downward spiral, the environment becomes less munificent. Only those firms with slack are able to survive such a change in the environment (Hambrick and D'Aveni, 1988). Sudden changes in the environment, combined with low slack levels, exhaust all forms of slack and seal the firm's demise.

The threat-rigidity perspective argues that either a threat or a crisis induces managers to rigidity and a tightening of control (Staw et al., 1981). The process starts when decline results in managerial stress and anxiety. Managerial stress produces two relevant organizational responses (Arogyaswamy et al., 1995; Cameron et al., 1987b; Staw et al., 1981). First, managers step up the search for information, which triggers information overload. Information overload problems appear when the amount of information to be interpreted is larger than the amount the unit can adequately process (Huber, 1991). Information overload reduces a firm's absorptive capacity (Huber, 1991; Vermeulen and Barkema, 2002)—defined as the ability to absorb and apply knowledge for commercial use (Cohen and Levinthal, 1990). Second, managers tighten control and shift towards mechanistic structures and decision-making processes. Finally, Staw et al. (1981) argue that the degree of 
dysfunctionality of these responses depends on the conditions under which they occur, such as the environment (Staw et al., 1981).

\section{Timing of retrenchment}

The turnaround literature has argued and shown evidence that the probabilities of a successful turnaround are higher the earlier the timing of the intervention (Grinyer et al., 1992; Grinyer and Spender, 1988; Tangpong et al., 2015). First, as the downward spiral perspective argues, decline acts as a process of resource and performance erosion (Hambrick and D'Aveni, 1988). Decline depletes internal resources by eroding financial, human and reputational resources (Hambrick and D'Aveni, 1992, 1988; Sutton et al., 1986). Then, underperformance reduces the availability of external resources by driving off stakeholder support, further eroding slack (Gilson et al., 1990; Pajunen, 2006). This internal and external deterioration process accelerates as decline gathers pace (Hambrick and D'Aveni, 1992; Shein, 2013) on account of decline being a self- reinforcing process (Hambrick and D'Aveni, 1988).

However, the availability of slack internal resources and of stakeholder support are necessary for a successful turnaround (Arogyaswamy et al., 1995; Love and Nohria, 2005; Whetten, 1987).

Second, the threat-rigidity perspective describes how decline inflicts stress on managers (Staw et al., 1981). Research shows evidence that stress has a curvilinear relationship (inverted U-shaped) with performance (Rudolph and Repenning, 2002). Based on this shape, a moderate amount of stress can be positive for the firm. Notwithstanding, excessive levels of stress result in a decrease in performance. As a situation of intense decline generates extreme levels of stress, driving the firm to severe underperformance (Staw et al., 1981; Whetten, 1980), firms should avoid extended periods of decline. 
Therefore, we argue that an early timing of retrenchment, insofar as it halts an extended period of downward spiral, will prevent the depletion of slack resources (Grinyer et al., 1992; Tangpong et al., 2015) and avoid excessive levels of stress derived from a threat-rigidity situation. Therefore, we put forward our hypothesis:

Hypothesis 1a: An earlier timing of retrenchment is associated with higher firm performance.

\section{Timing of retrenchment and the environment}

As the environment becomes more dynamic, an early timing of retrenchment begins to be more important. First, dynamic environments aggravate the ability to predict the future because there is an absence of patterns (Dess and Beard, 1984; Sirmon et al., 2007). There are a number of alternatives to counter dynamism, such as introducing flexibility, experimenting, managing the firm as a portfolio of real options or simply building and using strong processing power (Farjoun and Levin, 2011; Morrow Jr. et al., 2007; Siggelkow and Rivkin, 2005). All of these alternatives require slack resources to operate (Cyert and March, 1963; Love and Nohria, 2005; Meyer, 1982; Siggelkow and Rivkin, 2005; Simsek et al., 2007). An early timing of retrenchment will mitigate the resource erosion arising from a downward spiral, and will enable the conservation of resources required to operate under conditions of dynamism.

Second, we argued earlier that, based on the threat-rigidity perspective, a process of intense decline generates decline-induced stress (D'Aveni and MacMillan, 1990; Staw et al., 1981; Whetten, 1980). Dynamism represents an added source of firm stress as executives of firms operating in unpredictable environments suffer stress and anxiety (Cameron et al., 1987a; Waldman et al., 2001). A situation that combines both decline and dynamism may generate 
extreme levels of stress, driving the firm to intense underperformance (Rudolph and Repenning, 2002). An early retrenchment will curtail excessive levels of stress. Third, under the threat-rigidity perspective, firms respond to decline by shifting to a mechanistic structure (Staw et al., 1981). Yet there is extensive evidence that, as the environment becomes more dynamic, organic structures are preferred on account of mechanistic structures being adverse to dynamic environments (Cameron et al., 1987a; Davis et al., 2009; Sutton and D'Aunno, 1989).

Based on the above reasoning, we expect an early timing of retrenchment to be advantageous to declining firms under conditions of high dynamism. An early retrenchment will halt the downward spiral period, conserving resources required to operate under dynamism. It will also avoid an extreme threat-rigidity situation, avoiding excessive levels of executive stress and a shift to mechanistic structures. Consequently, we argue:

Hypothesis 1b: Environmental dynamism positively moderates the relationship between an early timing of retrenchment and firm performance.

An early timing of retrenchment becomes more important as the environment starts to be more munificent. First, research describes a munificent environment as an environment rich in opportunities (Dess and Origer, 1987; Keats and Hitt, 1988), able to support high sales growth (Aragon-Correa and Sharma, 2003; Dess and Beard, 1984) and to provide declining firms with extra revenues (Boyne and Meier, 2009; Sheppard, 1995). In such an opportunityrich environment, declining firms delaying retrenchment will allow the downward spiral to further erode their internal resources and will possess fewer resources available to pursue those opportunities.

Second, a situation of decline can originate from internal and from external causes (Argenti, 1976a; Cameron et al., 1988; Davis, 1952; Trahms et al., 2013). External causes are 
environmentally-related and produce a firm's decline (Arogyaswamy et al., 1995). These include changes in the macro-environmental conditions, such as alterations in the business cycle (Balcaen and Ooghe, 2006), in the interest rates (Shein, 2013), in government regulations (Lawton et al., 2011), in the availability of credit (Balcaen and Ooghe, 2006) or environmental jolts (Trahms et al., 2013). Other changes covered are in the industry-specific conditions, such as technological changes (Trahms et al., 2013), the entry of new competitors with disruptive or more powerful business models (Lawton et al., 2011; Sheppard and Chowdhury, 2005), adjustments in the industry basis of competition (Burgelman, 1994) or a shift in consumer demand (Shein, 2013). An important implication is that "external forces will be more difficult to change, and therefore a company struggling with external causes of distress — all things being equal—will be a less attractive candidate..." (Shein, 2013: p. 267). Internal causes are firm-related causes leading to a firm's decline. The literature agrees that they are managerial in nature. The most common internal cause is ineffective management ${ }^{3}$ (Argenti, 1976a; Bruno and Leidecker, 1988; Trahms et al., 2013), which includes complacent or incompetent management (O'Kane and Cunningham, 2014), an unbalanced TMT (Slatter, 1984) or a weak finance function (Argenti, 1976b). Internal problems (causes) "are easier to resolve than external problems" (Hopkins and Hopkins, 2006: p. 9) due to their being brought about by the firm itself. Hence, the solution is in the firm's hands as well and the firm keeps full control of the turnaround process (Hopkins and Hopkins, 2006; Shein, 2013)

The turnaround literature posits that high munificence represents a benevolent environment, indicating that the firm is less affected by external environmental causes and more affected by internal causes (Arogyaswamy et al., 1995; Ndofor et al., 2013). This is why the firm will be able to halt the downward slide process earlier in a munificent environment, avoiding

\footnotetext{
${ }^{3}$ Several studies have estimated the percentage of failures in which ineffective management is the main reason to be as high as $85 \%$ (Bibeault, 1982; Bruno and Leidecker, 1988).
} 
excessive resource deterioration and extreme levels of managerial stress. Accordingly, we hypothesize:

Hypothesis 1c: Environmental munificence positively moderates the relationship between an early timing of retrenchment and firm performance.

\section{Speed of retrenchment}

The literature has consistently suggested that turnarounds require a fast pace of action (Bibeault, 1982; Choe and Roehl, 2007; Dowell et al., 2011; Pearce II and Robbins, 1993; Slatter et al., 2006), especially during the retrenchment stage (Arogyaswamy et al., 1995). There are two reasons for this. First, as argued earlier, the downward spiral perspective posits that decline depletes internal resources and reduces the availability of external resources (Gilson et al., 1990; Hambrick and D'Aveni, 1992, 1988; Pajunen, 2006; Sutton et al., 1986). A fast retrenchment process shortens the period of decline, reducing the period of resource erosion. For example, Lee et al., (2007) argue how the speed of the bankruptcy procedure improves the odds of survival by protecting the bankrupt firm's internal resources and external support.

Second, one of the responses to a threat-rigidity situation is the increase in the use of mechanistic structures and processes. Nevertheless, retrenchment reduces their use (Sutton and D'Aunno, 1989). As retrenchment gathers pace, the firm becomes smaller in size. As a consequence, it begins to be less complex, reduces its need for organization and control, and becomes less structurally mechanistic (Sutton and D'Aunno, 1989). A less structurally mechanistic firm is able to achieve faster decision-making (Cascio, 1993) and faster adaptive action (Sutton and D'Aunno, 1989). So, the faster the firm retrenches, the shorter the period it will spend operating as an inflexible complex organization. Finally, and also based on the 
threat-rigidity perspective, a fast pace of retrenchment will prevent excessive levels of managerial stress coming from extreme decline. Based on the above arguments, we posit the following hypothesis:

Hypothesis 2a: A faster pace of retrenchment is associated with higher firm performance.

\section{Speed of retrenchment and the environment}

Dynamism influences the effect of a fast pace of retrenchment on turnaround performance. First, as argued earlier, organizations possessing slack resources adapt better and respond more effectively to a dynamic environment (Cyert and March, 1963; Meyer, 1982; Simsek et al., 2007). A fast pace of retrenchment enables a firm to shorten the period of downward spiral, avoiding resource depletion (Lee et al., 2007). Those resources conserved as a consequence of a fast pace of retrenchment can then be used to operate more effectively in a dynamic environment.

Second, as argued by the threat-rigidity perspective, firms respond to decline by increasing mechanistic structures and processes (Staw et al., 1981). Nonetheless, retrenchment reduces firm size, complexity and the need for organization and control, and the firm becomes less structurally mechanistic (Sutton and D'Aunno, 1989). A less structurally mechanistic firm is more flexible and agile and thus more effective in dynamic environments (Baum and Wally, 2003; Davis et al., 2009; Siggelkow and Rivkin, 2005). For example, according to Dowell and Shackle (2011), small boards of distressed firms are more effective under dynamic conditions. In this type of setting the ability of declining firms to gather additional information is less valuable than "the ability to move quickly" (Dowell et al., 2011. p. 1028). Based on these arguments, we posit that a fast pace of retrenchment will produce earlier, more agile and 
flexible organizations which are fit to operate more effectively in dynamic environments (Sutton and D'Aunno, 1989). For this reason, we argue:

Hypothesis 2b: Environmental dynamism positively moderates the relationship between the speed of retrenchment and firm performance.

We also expect munificence to influence the performance of a fast pace of retrenchment. First, a fast pace of retrenchment requires more resources to be executed than does a standard pace. For example, an employee reduction program requires firms to pay the redundancy packages in advance. Another example is the sale of firm facilities, which requires hiring external consultants to seek a potential buyer. Under high munificence, declining firms will be able to attract more resources (Aragon-Correa and Sharma, 2003; Castrogiovanni, 1991; Dess and Beard, 1984), which will allow them to pace retrenchment fast. A faster pace of retrenchment shortens the downward spiral, avoiding resource erosion (Hambrick and D'Aveni, 1988; Lee et al., 2007) and permits an earlier reduction of firm size and complexity, and an increase in agility (Chowdhury and Lang, 1996; Sutton and D'Aunno, 1989).

Second, we noted earlier that firms in a highly munificent environment are affected by internal causes of decline (Arogyaswamy et al., 1995; Ndofor et al., 2013). As a consequence, the firm does not need to pace retrenchment measures to environmental (external) causes, it can do so as fast as it wishes. Pacing retrenchment fast will shorten the period of the downward slide, reducing resource erosion and the levels of stress, and the firm will become agile sooner. Thus, we posit:

Hypothesis 2c: Environmental munificence positively moderates the relationship between the speed of retrenchment and firm performance. 


\section{Rhythm of retrenchment}

The literature describes the benefits of a regular rhythm of change (Klarner and Raisch, 2013; Vermeulen and Barkema, 2002). By combining periods of change and stability with a similar length and intensity, a regular rhythm of change reduces the risk of information overload (Klarner and Raisch, 2013; Vermeulen and Barkema, 2002). The periods of stability provide a pause to assimilate knowledge, increase learning and reduce the negative effects of diseconomies of time compression (Diericx and Cool, 1989; Klarner and Raisch, 2013). Conversely, under an irregular rhythm of change, the concentration of information exceeds the amount that any given firm can process. Information overload leads to managerial stress (Hermann, 1963; Heylighen and Vidal, 2008) and, eventually, to firm underperformance (Rudolph and Repenning, 2002).

Information overload problems are more pronounced in declining firms ( $\mathrm{D}^{\prime}$ Aveni and MacMillan, 1990; Hermann, 1963; Staw et al., 1981). As noted, under the threat-rigidity perspective, decline-induced stress is associated with an increase in the search of information, resulting in information overload (Staw et al., 1981). Opting for an irregular rhythm of retrenchment results in excessive levels of stress, given that stress derives from both an irregular rhythm of change (Hermann, 1963; Heylighen and Vidal, 2008; Klarner and Raisch, 2013) and a situation of decline (Staw et al., 1981). Thus, firms retrenching irregularly will underperform under severe levels of stress, while those retrenching regularly will perform better under moderate levels of stress.

However, there are some arguments supporting the opposite hypothesis: a lower performance by firms retrenching regularly. Those periods of stability, during which firms pause for information processing and reduce information overload, are periods of inaction in which the firm spirals downwardly and its resources are eroded. A type of retrenchment concentrated 
in time and intensity, that is an irregular rhythm of retrenchment, will therefore avoid an excessive deterioration of resources. As we deem both arguments to be equally strong, we argue the following two hypotheses:

Hypothesis 3a1: An irregular rhythm of retrenchment is associated with higher firm performance.

Hypothesis 3a2: A regular rhythm of retrenchment is associated with higher firm performance.

Rhythm of retrenchment and the environment

The uncertainty and turbulence originated by dynamism generates stress and anxiety among executives (Cameron et al., 1987a; Waldman et al., 2001). For those firms retrenching irregularly, dynamism is then a third source of stress beyond the decline (Staw et al., 1981; Whetten, 1980) and the irregularity of retrenchment (Klarner and Raisch, 2013). By retrenching regularly, the periods of stability during which the firm does not retrench will permit it to reduce the levels of stress and the negative effects of information overload. Thus, we expect that firms will perform better when they retrench regularly in dynamic environments.

Still, we can also argue the opposite. Those periods of stability enjoyed by regularly retrenching firms in dynamic environments will result in resource erosion and we can expect them to underperform. As we consider both arguments to be equally solid, we posit the following two hypotheses:

Hypothesis 3b1: Environmental dynamism positively moderates the relationship between an irregular rhythm of retrenchment and firm performance. 
Hypothesis 3b2: Environmental dynamism positively moderates the relationship between a regular rhythm of retrenchment and firm performance.

This tradeoff between following a regular or irregular rhythm under dynamism, balances under munificence toward following an irregular pace of retrenchment. Munificence allows declining firms to mitigate the downside of an irregular pace and to benefit from the upside of this pace. First, the major downside of an irregular rhythm is the generation of information overload. The literature supports that information overload can be reduced with the provision of slack resources used to process information (Day and Schoemaker, 2004; Edmunds and Morris, 2000; Koniger and Janowitz, 1995). A munificent environment provides firms with slack resources to be used for information processing (Boyne and Meier, 2009; Dess and Beard, 1984; Keats and Hitt, 1988). Second, irregular retrenchment shortens the period of downward slide and reduces resource erosion. Accordingly, we put forward our hypothesis:

Hypothesis 3c: Environmental munificence positively moderates the relationship between an irregular rhythm of retrenchment and firm performance.

\section{Methodology}

\section{Sample}

Our aim was to study companies in a turnaround situation implementing retrenchment measures. We used data from the Standard \& Poor's Compustat quarterly files to select firms in decline between 1983 and 2009 which applied retrenchment measures. We chose a sufficiently ample time period to include periods of expansion and periods of recession (Morrow et al., 2004). The literature notes that the selection of an appropriate sample of declining firms is very important for the study of turnarounds (Barker III and Duhaime, 
1997). The literature considers declining firms to be firms experiencing a period of decline (Ndofor et al., 2013). Prior research has measured decline as a period of several consecutive years of declining performance, preceded by several years of positive performance (Barker and Mone, 1994; Robbins and Pearce, 1992). Based on the extant literature, we considered a declining firm to be one which accumulates two years of increasing ROI, followed by three years of decreasing ROI (Morrow et al., 2004). This criterion eliminates those firms incurring in a sharp correction due to accounting anomalies rather than actual decline (Ndofor et al., 2013). Further, the average Altman's Z-score of our sample was 2.10, denoting a considerable risk of bankruptcy. Our sample's average Z-score was well below other turnaround studies (Chen, 2014; Chen and Hambrick, 2012; Latham and Braun, 2009) and similar to other bankruptcy studies (Dawley et al., 2002).

In order to exclude small and medium-sized firms, we used only those firms that had more than 500 employees (Bibeault, 1982; Chen, 2014; Lim et al., 2013). Also, we chose relatively undiversified firms to avoid an amalgamation between activities. We used the entropy measure, which uses the relationship between business units sales and total firm sales, to capture the extent of diversification (Hoskisson et al., 1993). We only included in our sample those firms with an entropy score equal to zero (Morrow et al., 2004). We just used those firms operating in the manufacturing industry; that is, firms with US SIC codes between 2000 and $4000^{4}$ (Dawley et al., 2002; Morrow et al., 2004). This selection procedure yielded a total of 734 firms. From this subsample, we selected those firms implementing either asset retrenchment or cost retrenchment. We considered firms undergoing asset retrenchment to be those reducing total assets by more than 5\% during the five years following the first year of decline in ROI. We regarded firms experiencing cost retrenchment to be those decreasing SGA (selling, general and administrative) costs by more than $5 \%$ during the five years after

\footnotetext{
4 The proportion of firms in our sample in each two-digit US SIC industry matches that of the Compustat dataset. A table comparing both samples is available from the authors upon request.
} 
the first year of decline in ROI (Lim et al., 2013; Morrow et al., 2004; Ndofor et al., 2013).

We found 479 firms not involved in retrenchment processes, thus we excluded them from our sample. Applying the above criteria, our sample was reduced to 263 firms. If a firm met these requirements more than once over the period, in our analysis we used data from the first time the requirements were met (Barker and Mone, 1994; Morrow et al., 2004).

The sample constituted an unbalanced panel as a result of some of the firms in our sample being liquidated, acquired, delisted, etc. The inclusion of those firms in the sample is subject to survival bias and is one of the major criticisms of sampling turnaround firms (Barker and Mone, 1994; Ndofor et al., 2013). We performed analyses of the variance (ANOVAs) comparing performance, number of employees and total assets between surviving and nonsurviving firms. We did not find significant differences between both groups in the two-year period of pre-decline and in the three-year period of decline (Ndofor et al., 2013). We did find differences however in the post decline period ${ }^{5}$.

\section{Period of study}

Previous turnaround studies have used up to six years starting from the third year of decline. We used an eight-year period of study. Yet our analysis started the first year of decline. We wanted to avoid missing the fact that some firms initiated the turnaround during the first three years of decline. So, in our study we took eight years in total, which included the three-year period of decline and a post decline period of five years.

\section{Dependent variable}

As the choice of a performance variable can be challenging due to the multi-dimensionality of organizational performance (Miller et al., 2013), we carefully selected our dependent variable. We used a market variable for our research. First, market variables are common to

\footnotetext{
${ }^{5}$ Results for the ANOVA analyses comparing surviving and non-surviving firms are available upon request.
} 
both turnaround studies (Chen and Hambrick, 2012; Morrow et al., 2004; Norman et al., 2012) and time studies (Pacheco-de-Almeida et al., 2015). We used Tobin's Q as the measure of return and as our dependent variable. Tobin's Q has previously been used in time research (Pacheco-de-Almeida et al., 2015) because the variable captures intangible capabilities (Dowell et al., 2000), and time capabilities have been previously considered as intangible (Pacheco-de-Almeida et al., 2015, 2010). Turnaround studies have also used Tobin's Q as a measure of the firm's perceived ability to achieve the returns required by investors (Morrow et al., 2004). The prior literature has argued that Tobin's $Q$ is a better measure of firm value than accounting variables, such as ROA or ROS (Dushnitsky and Lenox, 2006; Yang et al., 2014), and does not require risk adjustment to compare across firms (Li and Tallman, 2011). We calculated Tobin's Q as the sum of a firm's equity value, its book value of the long term debt and its net current liabilities, divided by the total assets of the firm (Pacheco-de-Almeida et al., 2015). Second, we also used a market variable due to the design of our control model. As we argued earlier, the literature has strongly criticized those turnaround studies which did not control for the causes of decline (Arogyaswamy et al., 1995; Barker III and Duhaime, 1997). We did include controls for the causes of decline (see below "Control Variables" section). The variable used to control for the internal causes of decline was based on the accounting variable Return on Sales. As accounting variables tend to be highly correlated between each other, and in order to avoid correlation with this important control variable, we used a market variable as our dependent variable. We lagged our variable to reflect the delay effects of retrenchment measures on firm performance. We introduced a three-year (twelve quarters) lag in our analyses (Lim et al., 2013; Morrow et al., 2004), but we used a two-year (eight quarters) lag for robustness purposes. 
Our independent variables included three time-related variables (timing, speed and rhythm of retrenchment) and two external environment variables (munificence and dynamism). We constructed the time related variables as a derivation of the variable retrenchment. We created the variable retrenchment as the sum of the standardized score of asset retrenchment and cost retrenchment. We calculated asset retrenchment as the percent change in the firm total assets from one quarter to the next. Cost retrenchment was calculated as the percent change in the cost of SGA from one quarter to the next. Reliability analysis indicated that asset retrenchment and cost retrenchment had a Cronbach's Alpha (Cronbach $\alpha=0.74$ ) exceeding the 0.7 acceptability level (Nunnally, 1978). Therefore, the results were mean centered and added to form one variable. This variable was used both to generate the three time variables (timing, speed and rhythm of retrenchment) and as a control variable (retrenchment).

Following other time and change studies (Bridoux et al., 2013; Elfenbein and Knott, 2014), we measured our three time variables as the number of quarters between the initiation of the event and the end of the event. We measured the timing of retrenchment as the count of the number of quarters between the quarter in which decline was initiated and the quarter in which retrenchment was started. We measured the speed of retrenchment as the number of quarters between the quarter in which retrenchment was initiated and the quarter in which the firm completed $90 \%$ of the retrenchment program. For robustness purposes, we used different percentages to calculate the speed of retrenchment. We describe those robustness tests in the “Robustness Check" section below. Following Vermeulen and Barkema (2002), we operationalized the rhythm of retrenchment as the kurtosis of the first derivative of the retrenchment variable over time for the study period. Finally, we reverse coded these four variables in order to facilitate an interpretation of the results. Greater values of retrenchment or greater values of the timing, speed or rhythm of retrenchment indicate deeper cuts, an early initiation of retrenchment, a faster pace of retrenchment or a regular rhythm of retrenchment. 
Finally, these four variables are shown in a mean-centered form given that they derive from the variable retrenchment, which had been mean centered. Mean centering avoids collinearity problems in the interaction-effects analyses.

We estimated our external environment variables, dynamism and munificence, using quarterly data (Patel and Cooper, 2014) to remain consistent with the rest of the variables. Dynamism was measured by dividing the standard error of the slope coefficient by the mean value of sales at the 4-digit SIC level for a twenty-quarter period (Boyd, 1990). Munificence was measured by the slope of the regression of time against total industry sales at the 4-digit SIC level for a twenty-quarter period divided by the mean value (Boyd, 1990).

\section{Control variables}

As cited earlier, one of the major criticisms in turnaround research has been the lack of control for the causes of decline. There is an extensive literature arguing a strong connection between external causes of decline and munificence or industry growth (Arogyaswamy et al., 1995; Barker III and Duhaime, 1997; Carmeli and Schaubroeck, 2008; Weitzel and Jonsson, 1989). This literature also suggests that controlling for those causes should be operationalized with an industry growth variable (Barker III and Duhaime, 1997). We controlled external causes with the variable munificence. As a measure for internal causes, we introduced a variable reflecting the wedge between the average industry performance and the firm's performance (Lim et al., 2013). This variable reflects sub-par performance and is consistent with Argogyaswamy et al.’s (1995: p. 507) idea that internal causes occur when firms "perform worse than the average firm in the industry". To calculate this variable, ideally we could have used ROI for consistency purposes, which is the accounting variable used for declining firm sample selection. Finally, given the suggestions of other authors on the use of accounting variables to measure performance (Lim et al., 2013; Trahms et al., 2013), we 
opted for using ROS. We calculated internal causes by subtracting the industry average ROS from the firm's ROS. Higher values of internal causes represent internal causes being more important in the decline of the firm.

Beyond the causes of decline, and as additional control variables we included firm size, liquidity, leverage, and severity of decline. As discussed earlier, we also included retrenchment itself as a control variable. We controlled for firm size since evidence has shown that smaller organizations have higher levels of inertia leading to a lower intensity of reorganization (Baker and Cullen, 1993; Barker III et al., 2001). We measured firm size as the number of employees. This variable was log formed. Besides having being used consistently by the turnaround literature as control variables, declining firm liquidity, leverage and severity are likely to affect how early, fast or regularly a firm can retrench. Liquidity was estimated as the current ratio. This variable was calculated by dividing the current assets by the current liabilities (Morrow et al., 2004; Schmitt and Raisch, 2013). Leverage was operationalized as the long term debt to asset ratio (Lim et al., 2013). Severity of decline was operationalized as the Altman's Z (Barker III et al., 2001). We have described earlier in the independent variables section the estimation of the variable retrenchment due to our using it to operationalize the three time variables.

Finally, we introduced two types of time dummies. First, we used four quarterly dummies to control for seasonality (Bridoux et al., 2013; Elfenbein and Knott, 2014). Second, we introduced period dummy variables with a view to controlling for the economic cycle in which decline occurred. Period dummies are common in studies spanning a long time horizon (Briscoe et al., 2014; Pathak et al., 2013; Whittington et al., 2016). In line with other studies, we used four decade dummies representing the decade in which the firm obtained the first loss within the period of decline (Elfenbein and Knott, 2014; Pathak et al., 2013). 


\section{Estimation Method}

Given the characteristics of our data, potential problems of heteroscedasticity were likely. The presence of heteroscedasticity does not violate the consistent assumption of the ordinary least squares (OLS) estimator, but does violate the efficiency assumption. As a result, OLS was not the best possible estimator. To handle such problems we used the feasible generalized least squares (FGLS) approach (Wooldridge, 2009). The FGLS estimator permits the obtaining of unbiased, consistent, efficient, and asymptotically normal estimators (Kariya and Kurata, 2004).

\section{Results}

The descriptive statistics and correlations for all the variables used (excluding time and quarterly dummies) appear in Table 2. The table includes the variance inflation factors. The factors denote that multicollinearity is not a problem in our analyses as none of the factors approaches the threshold of 10 (Aiken and West, 1991). The factor with the highest value is 2.33. In any case, to definitely exclude multicollinearity problems, all the independent variables were mean centered prior to the creation of the interaction terms (Aiken and West, 1991).

Table 3 presents the empirical results of our panel regression. The models also include time and quarterly dummy variables to account for the unobservable effects of the business cycle and seasonality, respectively. Model 1 presents the control model. Model 2 shows the results for the main effects model (Hypotheses 1a, 2a and 3a1/3a2). Model 3 has the results for the interactions of timing, speed and rhythm of retrenchment with dynamism (Hypotheses $1 b, 2 b$ and $3 \mathrm{~b} 1 / 3 \mathrm{~b} 2$ ). Model 4 gives the results for the interactions of timing, speed and rhythm of retrenchment with munificence (Hypotheses 1c, 2c and 3c). 
Our hypotheses 1a, 2a and 3a2 proposed that an early timing, a fast pace and a regular rhythm of retrenchment lead to higher firm performance. Our results in Model 2 confirm hypotheses $1 \mathrm{a}$ and $2 \mathrm{a}$ as they show that an early timing $(\beta=0.031, \mathrm{p}<0.001)$ and a fast pace of retrenchment $(\beta=0.064, \mathrm{p}<0.001)$ influence performance. Model 2 also shows that the coefficient for the rhythm of retrenchment is positive $(\beta=0.024, \mathrm{p}<0.001)$, denoting a regular rhythm of retrenchment. Thus, our results confirm hypothesis $3 \mathrm{a} 2$ which stated a positive effect of a regular rhythm of retrenchment on firm performance, and reject hypothesis $3 \mathrm{a} 1$.

Our hypothesis $1 \mathrm{~b}$ posited that dynamism strengthens the effects of an early timing of retrenchment on firm results. Nevertheless, as our results show in Table $3(\beta=-0.017, p<$ 0.01) and as Figure 3a depicts, when dynamism is high, an early timing of retrenchment brings about the opposite: a lower performance. In contrast, as predicted by our hypothesis $2 \mathrm{~b}$ and as shown in Model 3, a fast pace of retrenchment $(\beta=0.014, \mathrm{p}<0.01)$ produces higher firm performance when dynamism is high (Figure 4a). Model 3 also confirms our hypothesis $3 \mathrm{~b} 2$ which states that, under conditions of high dynamism, an irregular pace of retrenchment brings about a higher performance $(\beta=-0.052, \mathrm{p}<0.05$; the negative coefficient is due to the coding of the rhythm variable as an irregular rhythm for lower values and a regular rhythm for higher values). Figure 5a portrays this effect.

Hypotheses 1c, 2c and 3c proposed that an early timing, a fast speed and an irregular rhythm of retrenchment result in a higher firm performance under conditions of high munificence. Our results in Model 4 confirm that in a high munificent environment an early timing of retrenchment (Hypothesis 1c: $\beta=0.033, \mathrm{p}<0.001$ ) engenders higher firm performance (Figure 3b). Model 4 also confirms our hypothesis that in a highly munificent environment an irregular rhythm of retrenchment produces a higher performance (Hypothesis 3c: $\beta=-0.141$, 
$\mathrm{p}<0.001$; the negative coefficient is again due to the coding of the rhythm variable). Figure $5 \mathrm{~b}$ depicts this effect. Our results are not able to confirm that a fast pace of retrenchment results in a greater profitability in a highly munificent environment (Hypothesis 2c). In relation to our control model, the results show that most of the variables are significant for all the models. Specifically liquidity, leverage, firm size and severity are significant for all the models. The results of our control model are in line with the results obtained in the existing turnaround literature (Barker III et al., 2001; Morrow et al., 2004; Ndofor et al., 2013; Schmitt and Raisch, 2013) and the time literature (Hawk et al., 2013; Pacheco-de-Almeida et al., 2015).

\section{Robustness check}

To increase the reliability of our results, we used a quadratic specification for our timing, speed and rhythm of retrenchment since the literature has argued in favor of a quadratic relationship for retrenchment (Schmitt and Raisch, 2013). Second, we re-estimated the models using two-year lags (eight quarters) of the dependent variable, consistent with research by some turnaround studies (Morrow et al., 2004). Finally, we re-estimated our models by calculating the speed of retrenchment based on $75 \%$ and $80 \%$ of the retrenchment completion, instead of the $90 \%$ criterion used in our study. In all these three cases, the results are highly consistent with those reported here. These additional tests increase our confidence in the validity of our results ${ }^{6}$.

\footnotetext{
${ }^{6}$ The results for these three sets of analyses are available upon request.
} 


\section{Discussion}

The turnaround literature has consistently argued (Arogyaswamy et al., 1995; Bibeault, 1982; Grinyer and Spender, 1988; Slatter et al., 2006) but has showed scant evidence (Tangpong et al., 2015) that time issues are critical. We extend the study of time to the influence of the external environment. Applying the downward spiral and the threat-rigidity perspectives, we posit and find that the influence of the temporal dimensions of retrenchment on turnaround success is highly contingent on the type of environment the firm operates in. Our results indicate that an early timing of retrenchment results in lower returns in dynamic environments and higher returns in munificent environments. We also find that under high dynamism a fast pace and an irregular rhythm of retrenchment produce superior returns. Finally, we observe that under high munificence an irregular rhythm of retrenchment leads to a higher likelihood of turnaround.

Our research indicates that, with exceptions based on the type of environment, the general rule is that declining firms should be more time aggressive when executing retrenchment measures. Yet they should be more time aggressive in munificent environments than in dynamic environments. To illustrate our findings, we have provided a description of the restructuring actions over time executed by two companies in our sample: one that is successful and another one which is unsuccessful in their turnaround efforts, operating in the type of environment of our study (see Exhibit 1).

\section{INSERT EXHIBIT 1 ABOUT HERE}

\section{Theoretical implications}


Our research contributes and expands the turnaround literature in several ways. First, it adds to the scant but important literature confirming the importance of time to turnarounds (Tangpong et al., 2015). Recent studies have showed evidence of the importance of the timing to retrenchment (Tangpong et al., 2015) and to downsizing (Brauer and Laamanen, 2014). We contribute to those discussions by extending the temporal framework to two other important variables: the speed and rhythm of retrenchment. We find that in the study of time and turnarounds not only the "when" of retrenchment (timing) is important (Tangpong et al., 2015), but also the "how" of retrenchment. That is, "how" fast or slow (the speed of retrenchment) and "how" regular or irregular (the rhythm of retrenchment) its execution should be.

Second, turnaround studies have shown contradictory evidence on the value of retrenchment (Barker and Mone, 1994; Robbins and Pearce, 1992; Trahms et al., 2013). Nonetheless, those studies have not taken into account the time dimension, which appears as a long discussed but hardly researched critical factor. Our evidence confirms the sparse but growing literature showing evidence that "without such temporal considerations, the extant theoretical perspective on retrenchment and turnarounds is incomplete" (Tangpong et al., 2015: p. 672). Furthermore, when time considerations are included in the analysis, retrenchment is a strategy which positively influences turnaround outcomes. Our evidence confirms the suggestion by the downward slide perspective, and the extensive number of hints by the turnaround literature, that time is important to turnarounds. This evidence also seems to confirm the suggestion in the seminal study by Pearce II and Robbins (1993) that time (duration) is one of the three salient dimensions of retrenchment. As a consequence, it appears that given its importance, future studies should introduce some form of control for the time conditions of the declining firms under study. 
Third, in most areas of management there exists an abundant body of research dealing with the effects of the environment on firm performance. In the case of turnarounds, the environment has tended to be studied as a secondary topic (Boyne and Meier, 2009) despite early seminal works pointing to how critical it is for the study of decline (Hambrick and D'Aveni, 1988; Staw et al., 1981). Also, the recent turnaround and decline literatures have documented the impact on turnaround outcomes of environmental changes, such as changes in the industry basis of competition (Burgelman, 1994), the entry of more powerful competitors (Sheppard and Chowdhury, 2005) and changes in governmental regulations (Lawton et al., 2011). If the turnaround literature essentially studies the reversal of a declining firm resource erosion process, and the environment can act as a resource facilitator, the environment should be a core topic to turnarounds. Our paper is one of the few (Abebe et al., 2011) which simultaneously research time and the two most studied environment variables, dynamism and munificence. Furthermore, the causes of decline are the most numerous, important and well-founded criticisms of turnaround studies (Arogyaswamy et al., 1995; Barker III and Duhaime, 1997). Studies failing to consider the causes of decline can lead to a lack of consistent results (Arogyaswamy et al., 1995) or to a wrong attribution of failure (Boyne and Meier, 2009). Recent studies have opted for dealing with this problem with the use of environmental variables (Chen, 2014; Tangpong et al., 2015). In our case, the study of the environment has enabled us to control for the causes of decline and overcome this major research problem. In a nutshell, our paper contributes to giving the topic of the environment the importance that it deserves in turnaround research.

Fourth, we extend the downward spiral and threat-rigidity perspectives by linking them to the study of time and the environment. This extension is natural and produces an excellent fit because of the longitudinal nature of the downward spiral perspective and the inclusion of the environment as a key element to both streams. We extend the downward spiral perspective by 
aligning the longitudinal nature of the decline model with the temporal traits of the retrenchment actions required to reverse decline. Also, we extend the threat-rigidity perspective by arguing that the firm's responses to decline predicted by this perspective influence the "when" and the "how" of retrenchment and time when confronted with a given type of environment. By using both perspectives, we concur with other decline studies arguing the need for or use of a multi-pluralistic theory building approach when situations, such as the study of decline, are complex (Latham and Braun, 2009; McKinley et al., 2014; Schmitt et al., 2016).

\section{Managerial implications}

Our findings also offer key insights for private equity investors, board members, CEOs and TMT members involved in turnarounds. From a strategy point of view, these actors should be aware that retrenchment decisions impacting firm strategy (the reduction or elimination of SKUs, products, business lines, geographic scope, etc.) are subject to important time and environmental considerations. Consequently, they should align the formulation and implementation of those decisions to the degree of time aggressiveness based on the type of environment.

Our findings suggest that in dynamic environments declining firms will improve their results through an initial thorough gathering of the information and strategic formulation, which will delay the start of the turnaround. This suggests that investors should seek to form larger and more diversified boards, outnumbered by non-executive members. First, larger boards possess a greater potential for bringing multiple perspectives to the formulation of the firm's strategy. Also, the choice of more diversified and more externally connected boards will help 
to develop more sophisticated strategies due to their greater potential for information gathering. Second, non-executive board members are more proactive in pushing firm change.

Our findings also suggest that under dynamism, boards should choose CEOs with greater experience in turnaround management. Experienced CEOs are able to execute the retrenchment process faster and in a more concentrated fashion. For these same reasons, CEOs ought to work, in turn, on structuring smaller but more cohesive and more turnaround experienced TMTs with decentralized powers. The TMT compensation, including the CEO, should be linked to milestones connected to the speed and rhythm of retrenchment. Finally, TMTs should work on speeding up the communication of the strategic changes across the organization and carrying out a fast and concentrated retrenchment process.

Under munificence, given that our findings suggest that early and concentrated retrenchment improves results, embarking on thorough strategic analysis will not improve performance. Quicker initial strategic formulation and early action seems key to firm survival. Then, investors ought to reduce the number of board members for an early kick start of the retrenchment process. Also, investors should assure a greater representation of executive board members because their knowledge of the firm will facilitate an early initiation as well. Boards should leave the firm's leadership in the hands of CEOs with greater turnaround experience. CEOs should in turn reduce the number of TMT members and decentralize decision making among those members. Compensation of CEO and TMT should be linked to an early and concentrated retrenchment. Additionally, TMTs should work on an early dissemination of the strategic changes throughout the organization.

Finally, our results also point to some implications for investor strategy on the choice of opportunity. In dynamic environments, investors should seek opportunities in industries which, based on prior investments, they are acquainted with. The capabilities and knowledge 
developed in the industry cost structure, the market for the transfer assets or labor relations will lead to superior returns by fast and concentrated retrenchment. In munificent environments, the acquisition of firms in the early stage of the decline cycle will ensure higher returns through early retrenchment. Also acquisitions in munificent industries previously invested in could be optimal for early and concentrated successful retrenchment.

\section{Limitations and Future Research}

Our work has a number of limitations. The turnaround literature has supported a model of two stages in which retrenchment precedes recovery. Our study has focused only on retrenchment, the first stage of a turnaround. Future studies should extend the research of time and the external environment to the recovery stage. In that case, we suspect the results of the study will show that munificence offers stronger benefits since firms are more stable during the recovery stage.

Secondly, to respond to the main criticism in turnaround studies, we have included two variables to control for the causes of decline. The chosen variables are simplistic, however, as the literature has identified a great number of causes of decline (Bibeault, 1982; Slatter et al., 2006). Despite the difficulty this entails, our study would benefit from a more sophisticated mechanism to control for the different causes of decline.

\section{Conclusions}


Our study builds on the largely unexplored but critical topic of time in a turnaround setting. Turnaround research has predominantly focused on the study of retrenchment from a volume standpoint, whereas this study adopts a time perspective. Little attention has been paid to the effect of the time dimensions of retrenchment on turnaround performance, and in particular to how the environment interacts with them. By studying these questions, we provide insights concerning the degree of time aggressiveness to be exerted in retrenchment processes in dynamic or munificent environments. We also provide a framework to analyze the time decisions of declining firms and hope that this will inspire future research to include this key study topic. 


\section{Acknowledgements}

This article is the result of a balanced effort by the authors and two anonymous reviewers to whom we remain thankful for their exceptional commitment. We are also grateful to the editor for his guidance throughout the review process.

\section{References}

Abebe, M.A., Angriawan, A., Liu, Y., 2011. CEO Power and Organizational Turnaround in Declining Firms: Does Environment Play a Role? J. Leadersh. Organ. Stud. 18, 260-273.

Aiken, L.S., West, S.G., 1991. Multiple Regression: Testing and Interpreting Interactions. Sage Publications, Newbury Park, CA.

Amis, J., Slack, T., Hinings, C.R., 2004. The pace, sequence, and linearity of radical change. Acad. Manag. J. 47, 15-39.

Ancona, D.G., Goodman, P.S., Lawrence, B.S., Tushman, M.L., 2001a. Time: A new research lens. Acad. Manag. Rev. 26, 645-663.

Ancona, D.G., Okhuysen, G.A., Perlow, L.A., 2001b. Taking time to integrate temporal research. Acad. Manag. Rev. 26, 512-529.

Aragon-Correa, J., Sharma, S., 2003. A contingent resource-based view of proactive corporate environmental strategy. Acad. Manag. Rev. 28, 71-88.

Argenti, J., 1976a. Corporate Collapse. McGraw-Hill, Maidenhead.

Argenti, J., 1976b. Corporate planning and Corporate Collapse. Long Range Plann. 9, 12-17.

Arogyaswamy, K., Barker, V., Yasai-Ardekani, M., 1995. Firm Turnarounds: An Integrative Two-Stage Model. J. Manag. Stud. 32, 493-525.

Baker, D., Cullen, J., 1993. Administrative reorganization and configurational context: the contingent effects of age, size and change in size. Acad. Manag. J. 36, 1251-1277.

Balcaen, S., Ooghe, H., 2006. 35 years of studies on business failure: An overview of the classic statistical methodologies and their related problems. Br. Account. Rev. 38, 6393.

Barker, V.L., Mone, M.A., 1994. Retrenchment: cause of turnaround and consequence of decline? Strateg. Manag. J. 15, 195-205.

Barker III, V.L., Duhaime, I.M., 1997. Strategic change in the turnaround process: Theory and empirical evidence. Strateg. Manag. J. 18, 13-38.

Barker III, V.L., Patterson Jr., P.W., Mueller, G.C., 2001. Organizational causes and strategic consequences of the extent of top management team replacement during turnaround attempts. J. Manag. Stud. 38, 234-269. 
Baum, J.R., Wally, S., 2003. Strategic decision speed and firm performance. Strateg. Manag. J. 24, 1107-1129.

Bibeault, D., 1982. Corporate Turnaround. McGraw-Hill, New York.

Boyd, B., 1990. Corporate linkages and organizational environment: A test of the resource dependence model. Strateg. Manag. J. 11, 419-430.

Boyne, G.A., Meier, K.J., 2009. Environmental change, human resources and organizational turnaround. J. Manag. Stud. 46, 835-863.

Brauer, M., Laamanen, T., 2014. Workforce Downsizing and Firm Performance: An Organizational Routine Perspective. J. Manag. Stud. 51, 1311-1333.

Bridoux, F., Smith, K.G., Grimm, C.M., 2013. The Management of Resources: Temporal Effects of Different Types of Actions on Performance. J. Manage. 39, 928-957.

Briscoe, F., Chin, M.K., Hambrick, D.C., 2014. CEO ideology as an element of the corporate opportunity structure for social activists. Acad. Manag. J. 57, 1786-1809.

Bruno, A. V., Leidecker, J.K., 1988. Causes of new venture failure: 1960s vs. 1980s. Bus. Horiz. 31, 51-56.

Burgelman, R.R., 1994. Fading memories: A process theory of strategic business exit in dynamic environments. Adm. Sci. Q. 39, 24-56.

Cameron, K., Kim, M., Whetten, D., 1987a. Organizational effects of decline and turbulence. Adm. Sci. Q. 32, 222-240.

Cameron, K., Sutton, R., Whetten, D., 1988. Readings in organizational decline: Frameworks, research and prescriptions. Ballinger, Cambridge, MA.

Cameron, K., Whetten, D., Kim, M., 1987b. Organizational Dysfunctions of Decline. Acad. Manag. J. 30, 126-138.

Carmeli, A., Schaubroeck, J., 2008. Organisational Crisis-Preparedness: The Importance of Learning from Failures. Long Range Plann. 41, 177-196.

Cascio, W.F., 1993. Downsizing: What do we know? What have we learned? Acad. Manag. Exec. 7, 95-104.

Casillas, J.C., Acedo, F.J., 2013. Speed in the Internationalization Process of the Firm. Int. J. Manag. Rev. 15, 15-29.

Castrogiovanni, G., 1991. Environmental munificence: A theoretical assessment. Acad. Manag. Rev. 16, 542-565.

Chen, G., 2014. Initial compensation of new CEOs hired in turnaround situations. Strateg. Manag. J. 36, 1895-1917.

Chen, G., Hambrick, D.C., 2012. CEO Replacement in Turnaround Situations: Executive (Mis)Fit and Its Performance Implications. Organ. Sci. 23, 225-243.

Chen, M., Hambrick, D., 1995. Speed, stealth and selective attack: how small firms differ from large firms in competitive behavior. Acad. Manag. J. 38, 453-482. 
Choe, S., Roehl, T.W., 2007. What to Shed and What to Keep: Corporate Transformation in Korean Business Groups. Long Range Plann. 40, 465-487.

Chowdhury, S.D., Lang, J.R., 1996. Turnaround in small firms: An assessment of efficiency strategies. J. Bus. Res. 36, 169-178.

Cohen, W.M., Levinthal, D.A., 1990. Absorptive capacity: a new perspective on learning and innovation. Adm. Sci. Q. 35, 128-152.

Cyert, R.M., March, J.G., 1963. A behavioral theory of the firm. Prentice-Hall, Englewood Cliffs, NJ.

D'Aveni, R.A., MacMillan, I.C., 1990. Crisis and the content of managerial communications: A study of the focus of attention of top managers in surviving and failing firms. Adm. Sci. Q. 35, 634-657.

Datta, D.K., Guthrie, J.P., Basuil, D., Pandey, A., 2010. Causes and effects of employee downsizing: A review and synthesis. J. Manage. 36, 281-348.

Davis, D.J., 1952. An analysis of some failure data. J. Am. Stat. Assoc. 47, 113-150.

Davis, J.P., Eisenhardt, K.M., Bingham, C.B., 2009. Optimal structure, market dynamism, and the strategy of simple rules. Adm. Sci. Q. 54, 413-452.

Dawley, D.D., Hoffman, J.J., Lamont, B.T., 2002. Choice situation, refocusing, and postbankruptcy performance. J. Manage. 28, 695-717.

Day, G.S., Schoemaker, P.J.H., 2004. Driving through the Fog: Managing at the Edge. Long Range Plann. 37, 127-142.

Dess, G.G., Beard, D.W., 1984. Dimensions of organizational task environments. Adm. Sci. Q. 29, 52-73.

Dess, G.G., Origer, N.K., 1987. Environment, Structure, and Consensus in Strategy Formulation: A Conceptual Integration. Acad. Manag. Rev. 12, 313-330.

Diericx, I., Cool, K., 1989. Asset stock accumulation and sustainability of competitive advantage. Manage. Sci. 12, 1504-1511.

Dowell, G., Hart, S., Yeung, B., 2000. Do corporate global environmental standards create or destroy market value? Manage. Sci. 46, 1059-1074.

Dowell, G.W.S., Shackell, M.B., Stuart, N. V, 2011. Boards, CEOs, and surviving a financial crisis: Evidence from the internet shakeout. Strateg. Manag. J. 32, 1025-1045.

Dushnitsky, G., Lenox, M.J., 2006. When does corporate venture capital investment create firm value? J. Bus. Ventur. 21, 753-772.

Edmunds, A., Morris, A., 2000. The problem of information overload in business organisations: a review of the literature. Int. J. Inf. Manage. 20, 17-28.

Elfenbein, D.W., Knott, A.M., 2014. Time to exit: Rational, behavioral, and organizational delays. Strateg. Manag. J. 36, 957-975.

Farjoun, M., 2010. Beyond dualism: Stability and change as a duality. Acad. Manag. Rev. 35, 
$202-225$.

Farjoun, M., Levin, M., 2011. A Fractal Approach to Industry Dynamism. Organ. Stud. 32, $825-851$.

Gersick, C.J., 1994. Pacing strategic change: the case of a new venture. Acad. Manag. J. 37, $9-45$.

Gilson, S.C., John, K., Lang, L.H.P., 1990. Troubled debt restructurings. An empirical study of private reorganization of firms in default. J. financ. econ. 27, 315-353.

Grinyer, P., Mayer, D., McKiernan, P., 1992. Typologies of corporate recovery, in: Barrar, P., Cooper, C. (Eds.), Managing Organizations in 1992: Strategic Responses. Routledge, London, pp. 131-158.

Grinyer, P., Spender, J., 1988. Sharpbenders: The secrets of unleashing corporate potential. Basil Blackwell, Oxford.

Hambrick, D., 1985. Turnaround strategies, in: Guth, W. (Ed.), Handbook of Business Strategy. Warren, Gorham and Lamont, Boston, MA, pp. 101-132.

Hambrick, D., D'Aveni, R., 1992. Top team deterioration as part of the downward spiral of large corporate bankruptcies. Manage. Sci. 38, 1445-1466.

Hambrick, D., D'Aveni, R., 1988. Large corporate failures as downward spirals. Adm. Sci. Q. $33,1-23$.

Hawk, A., Pacheco-De-Almeida, G., Yeung, B., 2013. Fast-mover advantages: Speed capabilities and entry into the emerging submarket of atlantic basin LNG. Strateg. Manag. J. 34, 1531-1550.

Hermann, C.F., 1963. Some consequences of crisis which limit the viability of organizations. Adm. Sci. Q. 8, 82.

Heylighen, F., Vidal, C., 2008. Getting Things Done: The Science behind Stress-Free Productivity. Long Range Plann. 41, 585-605.

Hopkins, S., Hopkins, D., 2006. Crafting solutions for troubled businesses: A disciplined approach to diagnosing and confronting management challenges. Beard Books, Frederick, MY.

Hoskisson, R.E., Hitt, M.A., Johnson, R.A., Moesel, D.D., 1993. Construct validity of an objective (entropy) categorical measure of diversification strategy. Strateg. Manag. J. 14, $215-235$.

Huber, G., 1991. Organizational learning: the contributing processes and the literatures. Organ. Sci. 2, 88-115.

Huy, Q.N., 2001. Time, temporal capability, and planned change. Acad. Manag. Rev. 26, $601-623$.

Kariya, T., Kurata, H., 2004. Generalized least squares. John Wiley \& Sons, Chichester, West Sussex, England.

Keats, B.W., Hitt, M.A., 1988. A causal Model of Linkages Among Environmental 
Dimensions, Macro Organizational Characteristics, and Performance. Acad. Manag. J. 31, 570-598.

Klarner, P., Raisch, S., 2013. Move to the beat-rhythms of change and firm performance. Acad. Manag. J. 56, 160-184.

Koniger, P., Janowitz, K., 1995. Drowning in information, but thirsty for knowledge. Int. J. Inf. Manage. 15, 5-16.

Latham, S.F., Braun, M., 2009. Managerial risk, innovation, and organizational decline. J. Manage. 35, 258-281.

Lawton, T., Rajwani, T., O'Kane, C., 2011. Strategic reorientation and business turnaround: the case of global legacy airlines. J. Sttrategy Manag. 4, 215-237.

Lee, S., Peng, M.W., Barney, J.B., 2007. Bankruptcy law and entrepreneurship development: A real options perspective. Acad. Manag. Rev. 32, 257-272.

Levinthal, D.A., 1991. Random Walks and Organizational Mortality. Adm. Sci. Q. 36, 397420.

Li, S., Tallman, S., 2011. MNC strategies, exogenous shocks, and performance outcomes. Strateg. Manag. J. 32, 1119-1127.

Lim, D.S.K., Celly, N., Morse, E.A., Rowe, W.G., 2013. Rethinking the effectiveness of asset and cost retrenchment: The contingency effects of a firm's rent creation mechanism. Strateg. Manag. J. 34, 42-61.

Love, E.G., Nohria, N., 2005. Reducing slack: The performance consequences of downsizing by large industrial firms, 1977-93. Strateg. Manag. J. 26, 1087-1108.

McKinley, W., Latham, S., Braun, M., 2014. Organizational decline and innovation: Turnarounds and downward spirals. Acad. Manag. Rev. 39, 88-110.

Meyer, A.D., 1982. Adapting to environmental jolts. Adm. Sci. Q. 27, 515-537.

Miller, C.C., Washburn, N.T., Glick, W.H., 2013. The Myth of Firm Performance. Organ. Sci. 24, 948-964.

Miller, D., Friesen, P., 1982. Innovation in conservative and entrepreneurial firms: Two models of strategic momentum. Strateg. Manag. J. 3, 1-25.

Morgeson, F., Mitchell, T., Liu, D., 2015. Event System Theory: An Event-oriented Approach to the organizational sciences. Acad. Manag. Rev. 40, 515-537.

Morrow, J.L., Johnson, R.A., Busenitz, L.W., 2004. The Effects of Cost and Asset Retrenchment on Firm Performance: The Overlooked Role of a Firms Competitive Environment. J. Manag. 30, 189-208.

Morrow Jr., J.L., Sirmon, D.G., Hitt, M.A., Holcomb, T.R., 2007. Creating value in the face of declining performance: Firm strategies and organizational recovery. Strateg. Manag. J. $28,271-283$.

Ndofor, H.A., Vanevenhoven, J., Barker, V.L., 2013. Software firm turnarounds in the 1990s: An analysis of reversing decline in a growing, dynamic industry. Strateg. Manag. J. 34, 
$1123-1133$.

Norman, P.M., Butler, F.C., Ranft, A.L., 2012. Resources Matter: Examining the Effects of Resources on the State of Firms Following Downsizing. J. Manage. 39, 2009-2038.

Nunnally, J., 1978. Psychometric methods. McGraw-Hill, New York.

O'Kane, C., Cunningham, J., 2014. Turnaround leadership core tensions during the company turnaround process. Eur. Manag. J. 32, 963-980.

Pacheco-de-Almeida, G., Hawk, A., Yeung, B., 2015. The right speed and its value. Strateg. Manag. J. 36, 159-176.

Pacheco-de-Almeida, G., Hawk, A., Yeung, B., 2010. Speed and Tobin's Q. Stern School of Business, New York University. New York.

Pajunen, K., 2006. Stakeholder influences in organizational survival. J. Manag. Stud. 43, $1261-1288$.

Patel, P.C., Cooper, D., 2014. Structural Power Equality between Family and Non-Family TMT Members and the Performance of Family Firms. Acad. Manag. J. 57, 1624-1649.

Pathak, S., Hoskisson, R.E., Johnson, R.A., 2013. Settling up in CEO compensation: The impact of divestiture intensity and contextual factors in refocusing firms. Strateg. Manag. J. 35, 1124-1143.

Pearce II, J.A., Robbins, K., 1993. Toward improved theory and research on business turnaround. J. Manage. 19, 613-636.

Robbins, D.K., Pearce, J.A., 1992. Turnaround: Retrenchment and recovery. Strateg. Manag. J. 13, 287-309.

Rudolph, J.W., Repenning, N.P., 2002. Disaster Dynamics: Understanding the Role of Quantity in Organizational Collapse. Adm. Sci. Q. 47, 1-30.

Schmitt, A., Barker, V.L., Raisch, S., Whetten, D., 2016. Strategic Renewal in Times of Environmental Scarcity. Long Range Plann. 49, 361-376.

Schmitt, A., Raisch, S., 2013. Corporate Turnarounds: The Duality of Retrenchment and Recovery. J. Manag. Stud. 50, 1216-1244.

Shein, J., 2013. Reversing the slide: A strategic guide to turnarounds and corporate renewal. Jossey-Bass, San Francisco, CA.

Sheppard, J.P., 1995. A Resource Dependence Approach To Organizational Failure. Soc. Sci. Res. 24, 28-62.

Sheppard, J.P., Chowdhury, S.D., 2005. Riding the wrong wave: Organizational failure as a failed turnaround. Long Range Plann. 38, 239-260.

Siggelkow, N., Rivkin, J.W., 2005. Speed and Search: Designing Organizations for Turbulence and Complexity. Organ. Sci. 16, 101-122.

Simsek, Z., Veiga, J.F., Lubatkin, M.H., 2007. The Impact of Managerial Environmental Perceptions on Corporate Entrepreneurship: Towards Understanding Discretionary 
Slack’s Pivotal Role. J. Manag. Stud. 44, 1398-1424.

Sirmon, D.G., Hitt, M.A., Ireland, R.D., 2007. Managing firm resources in dynamic environments to create value: Looking inside the black box. Acad. Manag. Rev. 32, 273292.

Slatter, S., 1984. Corporate recovery. Penguin Books, Harmandsworth, Middlesex.

Slatter, S., Lovett, D., Barlow, L., 2006. Leading corporate turnaround. John Wiley \& Sons, Chichester, West Sussex, England.

Smith, K.G., Grimm, C.M., Gannon, M.J., Chen, M., 1991. Organizational information processing, competitive responses and performance in the U.S. domestic airlines. Acad. Manag. J. 34, 60-85.

Staw, B.M., Sandelands, L., Sutton, J., 1981. Threat rigidity effects in organizational behavior: a multilevel analysis. Adm. Sci. Q. 26, 501-524.

Sutton, R., D'Aunno, T., 1989. Decreasing organizational size: untangling the effects of money and people. Acad. Manag. Rev. 14, 194-212.

Sutton, R., Eisenhardt, K.M., Jucker, J. V, 1986. Managing organizational decline: lessons from Atari. Organ. Dyn. 14, 17-29.

Tangpong, C., Abebe, M., Li, Z., 2015. A Temporal Approach to Retrenchment and Successful Turnaround in Declining Firms. J. Manag. Stud. 52, 647-677.

Trahms, C.A., Ndofor, H.A., Sirmon, D.G., 2013. Organizational Decline and Turnaround: A Review and Agenda for Future Research. J. Manage. 39, 1277-1307.

Vermeulen, F., Barkema, H., 2002. Pace, rhythm, and scope: Process dependence in building a profitable multinational corporation. Strateg. Manag. J. 23, 637-653.

Volberda, H.W., Van Den Bosch, F.A.J., Flier, B., Gedajlovic, E.R., 2001. Following the herd or not? Patterns of renewal in the Netherlands and the UK. Long Range Plann. 34, 209229.

Waldman, D.A., Ramirez, G.G., House, R.J., Puranam, P., 2001. Does leadership matter? CEO leadership attributes and profitability under conditions of perceived environmental uncertainty. Acad. Manag. J. 44, 134-143.

Weitzel, W., Jonsson, E., 1989. Decline in organizations: A literature integration and extension. Adm. Sci. Q. 34, 91-109.

Whetten, D., 1987. Organizational growth and decline processes. Annu. Rev. Sociol. 13, 335358.

Whetten, D.A., 1980. Organizational Decline: A Neglected Topic in Organizational Science. Acad. Manag. Rev. 5, 577-588.

Whitney, J.O., 1987. Taking charge: Management guide to troubled companies and turnarounds. Dow-Jones Irwin, Homewood, IL.

Whittington, R., Yakis-Douglas, B., Ahn, K., Cailluet, L., 2016. Strategic Planners in More Turbulent Times: The Changing Job Characteristics of Strategy Professionals, 1960- 
2003. Long Range Plann. In press.

Wooldridge, J.M., 2009. Introductory econometrics: A modern approach. South-Western, Mason, $\mathrm{OH}$.

Yang, Y., Narayanan, V.K., De Carolis, D.M., 2014. The relationship between portfolio diversification and firm value: The evidence from corporate venture capital activity. Strateg. Manag. J. 35, 1993-2011.

Zimmerman, F.M., 1991. The turnaround experience: real-world experiences in revitalizing corporations. McGraw-Hill, New York. 


\section{Table 1}

Summary of the temporal dimensions

\begin{tabular}{lll}
\hline Time dimension & \multicolumn{1}{c}{ Definition } & Relevance to retrenchment \\
\hline Timing & The moment an event happens or is planned to happen (Huy, 2001) & How early or late retrenchment is initiated \\
Speed & $\begin{array}{l}\text { The amount of time that a firm requires to achieve a target (Casillas and } \\
\text { Acedo, 2013; Chen and Hambrick, 1995) }\end{array}$ & How fast or slow retrenchment is executed \\
Rhythm & $\begin{array}{l}\text { The pattern of variability in the intensity and frequency of activity (Huy, How regular or irregular retrenchment is executed } \\
\text { 2001; Vermeulen and Barkema, 2002) }\end{array}$ & \\
\hline
\end{tabular}


Table 2

Descriptive statistics and correlations

\begin{tabular}{|c|c|c|c|c|c|c|c|c|c|c|c|c|c|c|c|c|c|c|}
\hline Variable & Mean & S.D. & Min & Max & VIF & 1. & 2. & 3. & 4. & 5. & 6. & 7. & 8. & 9. & 10. & 11. & 12. & 13. \\
\hline 1. Tobin's Q & 1.543 & 0.943 & 0.362 & 21.732 & & 1 & & & & & & & & & & & & \\
\hline 2. Tobin's $Q(t+3)$ & 1.566 & 0.854 & 0.362 & 8.384 & & 0.54 & 1 & & & & & & & & & & & \\
\hline 3. Liquidity & 2.269 & 1.411 & 0.139 & 24.987 & 2.33 & -0.06 & -0.16 & 1 & & & & & & & & & & \\
\hline 4. Leverage & 0.241 & 0.224 & 0.000 & 1.908 & 1.24 & -0.00 & 0.04 & -0.16 & 1 & & & & & & & & & \\
\hline 5. Size & 12.898 & 29.225 & 0.005 & 486 & 1.06 & 0.11 & 0.17 & -0.16 & -0.00 & 1 & & & & & & & & \\
\hline 6. Severity & 2.104 & 2.221 & -8.083 & 65.944 & 1.51 & 0.56 & 0.18 & 0.38 & -0.41 & -0.03 & 1 & & & & & & & \\
\hline 7. Internal causes & -1.814 & 10.255 & -194.671 & 175.292 & 1.13 & -0.07 & -0.07 & $\mathbf{0 . 0 0}$ & 0.02 & 0.02 & -0.03 & 1 & & & & & & \\
\hline 8. Munificence & 10.383 & 14.731 & 0.194 & 141.118 & 1.50 & 0.05 & 0.06 & 0.03 & -0.11 & -0.02 & 0.04 & -0.33 & 1 & & & & & \\
\hline 9. Dynamism & 4.950 & 13.905 & 0.014 & 448.726 & 1.47 & -0.01 & -0.01 & 0.02 & -0.09 & -0.02 & 0.02 & -0.11 & 0.56 & 1 & & & & \\
\hline 10. Retrenchment & -0.001 & 1.530 & -30.789 & 6.160 & 1.04 & 0.12 & 0.02 & -0.01 & -0.02 & -0.02 & -0.13 & 0.00 & $\mathbf{0 . 0 3}$ & 0.05 & 1 & & & \\
\hline 11. Timing & -0.000 & 1.560 & -6.926 & 1.926 & 1.11 & -0.07 & -0.04 & 0.00 & -0.00 & -0.01 & -0.05 & -0.04 & 0.05 & 0.01 & 0.05 & 1 & & \\
\hline 12. Pace & -0.002 & 1.705 & -3.009 & 6.371 & 1.12 & 0.06 & 0.12 & -0.06 & -0.08 & 0.01 & -0.01 & -0.03 & 0.04 & -0.02 & 0.00 & -0.21 & 1 & \\
\hline 13. Rhythm & -0.000 & 1.000 & -4.012 & 1.107 & 1.06 & -0.08 & -0.06 & 0.02 & -0.13 & -0.04 & -0.01 & -0.01 & 0.04 & 0.04 & 0.08 & 0.06 & -0.03 & 1 \\
\hline
\end{tabular}

$\mathrm{N}=3.042$. Correlations above $|0.1|$ are significant at $p<0.05$.

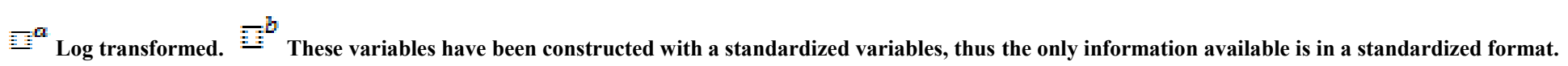


Table 3

Feasible Generalized Least Squares: Direct effects of timing, pace and rhythm on Tobin's Q $(t+12 q)$, and interaction effects of munificence and dynamism on timing, pace and rhythm on Tobin's Q (t+12q)

\begin{tabular}{|c|c|c|c|c|}
\hline & 1 & 2 & 3 & 4 \\
\hline \multicolumn{5}{|l|}{ Control variables } \\
\hline \multirow[t]{2}{*}{ Liquidity } & $-0.179 * * *$ & $-0.167 * * *$ & $-0.164 * * *$ & $-0.156^{* * *}$ \\
\hline & $(0.007)$ & $(0.007)$ & $(0.007)$ & $(0.007)$ \\
\hline \multirow[t]{2}{*}{ Leverage } & $0.725 * * *$ & $0.688 * * *$ & $0.696 * * *$ & $0.700 * * *$ \\
\hline & $(0.038)$ & $(0.043)$ & $(0.043)$ & $(0.043)$ \\
\hline \multirow{2}{*}{ Size $\stackrel{\bar{n} b}{=b}$} & $0.003 * * *$ & $0.003 * * *$ & $0.003 * * *$ & $0.004 * * *$ \\
\hline & $(0.000)$ & $(0.000)$ & $(0.000)$ & $(0.000)$ \\
\hline \multirow[t]{2}{*}{ Severity } & $0.283 * * *$ & $0.123 * * *$ & $0.123 * * *$ & $0.126 * * *$ \\
\hline & $(0.013)$ & $(0.006)$ & $(0.006)$ & $(0.006)$ \\
\hline \multirow[t]{2}{*}{ Retrenchment } & $0.014 * *$ & $0.009 *$ & 0.007 & 0.008 \\
\hline & $(0.004)$ & $(0.004)$ & $(0.004)$ & $(0.004)$ \\
\hline \multirow[t]{2}{*}{ Internal causes } & -0.001 & -0.005 & -0.006 & $-0.006 \dagger$ \\
\hline & $(0.018)$ & $(0.021)$ & $(0.021)$ & $(0.022)$ \\
\hline \multicolumn{5}{|l|}{ Main effects } \\
\hline \multirow[t]{2}{*}{ Dynamism } & & -0.001 & $0.034 \dagger$ & $0.020 * * *$ \\
\hline & & $(0.005)$ & $(0.017)$ & $(0.005)$ \\
\hline \multirow[t]{2}{*}{ Munificence } & & $0.016 \dagger$ & 0.005 & $0.017 \dagger$ \\
\hline & & $(0.009)$ & $(0.010)$ & $(0.010)$ \\
\hline \multirow[t]{2}{*}{ Timing (H1a) } & & $0.031 * * *$ & $0.031 * * *$ & $0.036 * * *$ \\
\hline & & $(0.004)$ & $(0.004)$ & $(0.004)$ \\
\hline \multirow[t]{2}{*}{ Speed (H2a) } & & $0.064 * * *$ & $0.066 * * *$ & $0.065 * * *$ \\
\hline & & $(0.004)$ & $(0.004)$ & $(0.004)$ \\
\hline \multirow[t]{2}{*}{ Rhythm (H3a) } & & $0.024 * * *$ & $0.017 *$ & -0.004 \\
\hline & & $(0.006)$ & $(0.008)$ & $(0.008)$ \\
\hline \multicolumn{5}{|l|}{ Interactions } \\
\hline \multirow[t]{2}{*}{ TimingXDynamism (H1b) } & & & $-0.017 * *$ & \\
\hline & & & $(0.007)$ & \\
\hline \multirow[t]{2}{*}{ SpeedXDynamism (H2b) } & & & $0.014 * *$ & \\
\hline & & & $(0.006)$ & \\
\hline \multirow[t]{2}{*}{ RhythmXDynamism (H3b1\&H3b2) } & & & $-0.052 *$ & \\
\hline & & & $(0.020)$ & \\
\hline \multirow[t]{2}{*}{ TimingXMunificence (H1c) } & & & & $0.033 * * *$ \\
\hline & & & & $(0.008)$ \\
\hline \multirow[t]{2}{*}{ PaceXMunificence $(\mathrm{H} 2 \mathrm{c})$} & & & & 0.004 \\
\hline & & & & $(0.005)$ \\
\hline \multirow[t]{2}{*}{ RhythmXMunificence (H3c) } & & & & $-0.141 * * *$ \\
\hline & & & & $(0.016)$ \\
\hline Constant & 1.969 & 1.694 & 1.677 & 1.663 \\
\hline Time dummies & Included & Included & Included & Included \\
\hline Quarterly dummies & Included & Included & Included & Included \\
\hline Chi-squared statistic & $1867.87 * * *$ & $3349.23 * * *$ & $4441.75^{* * *}$ & $2928.25 * * *$ \\
\hline Number of observations & 3042 & 3042 & 3042 & 3042 \\
\hline
\end{tabular}

$* * * p<0.001 ; * * p<0.01 ; * p<0.005 ; \dagger p<0.1$ 
Temporal dimensions of

retrenchment

Environmental variables

Turnaround

Performance

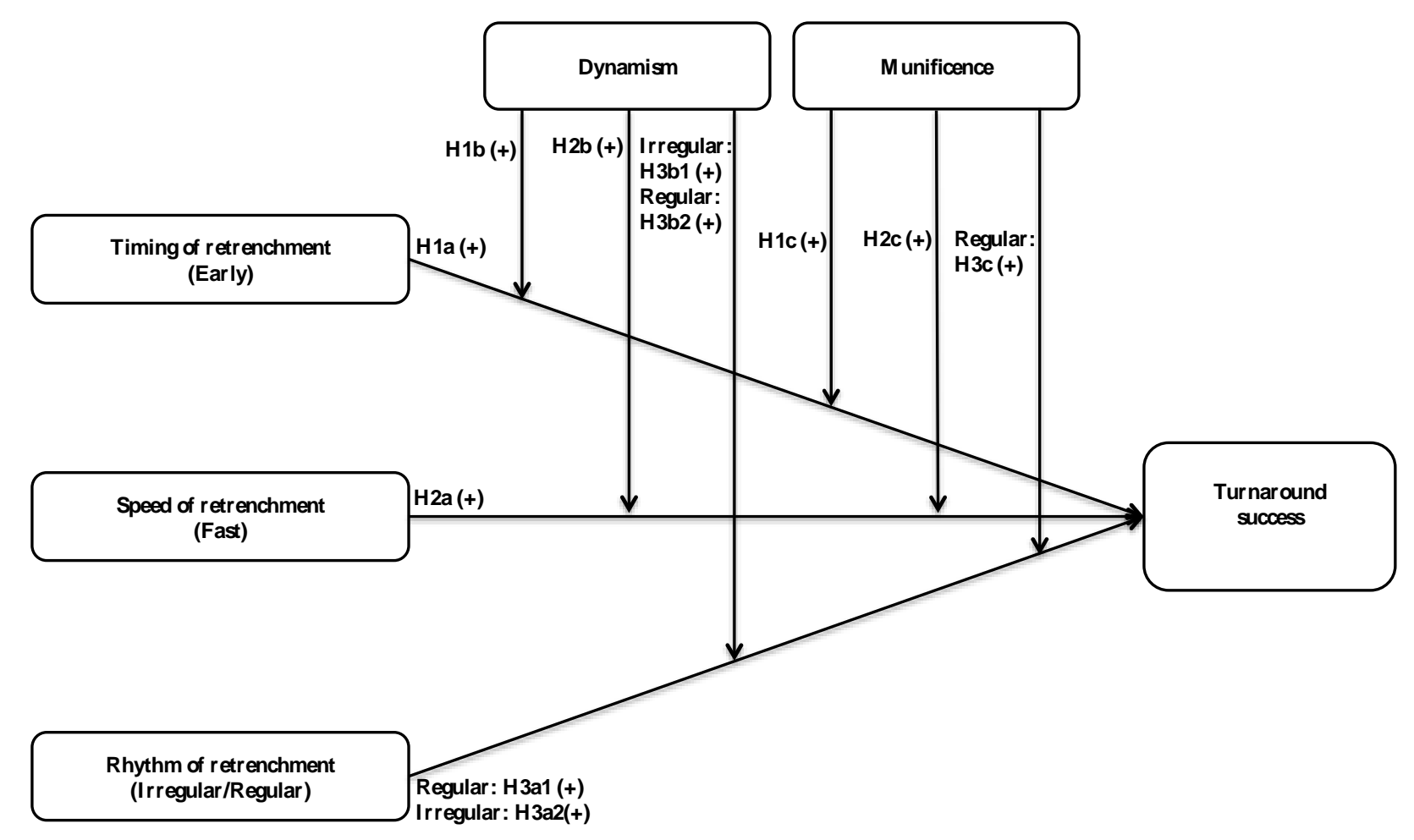

Figure 1. Conceptual model 


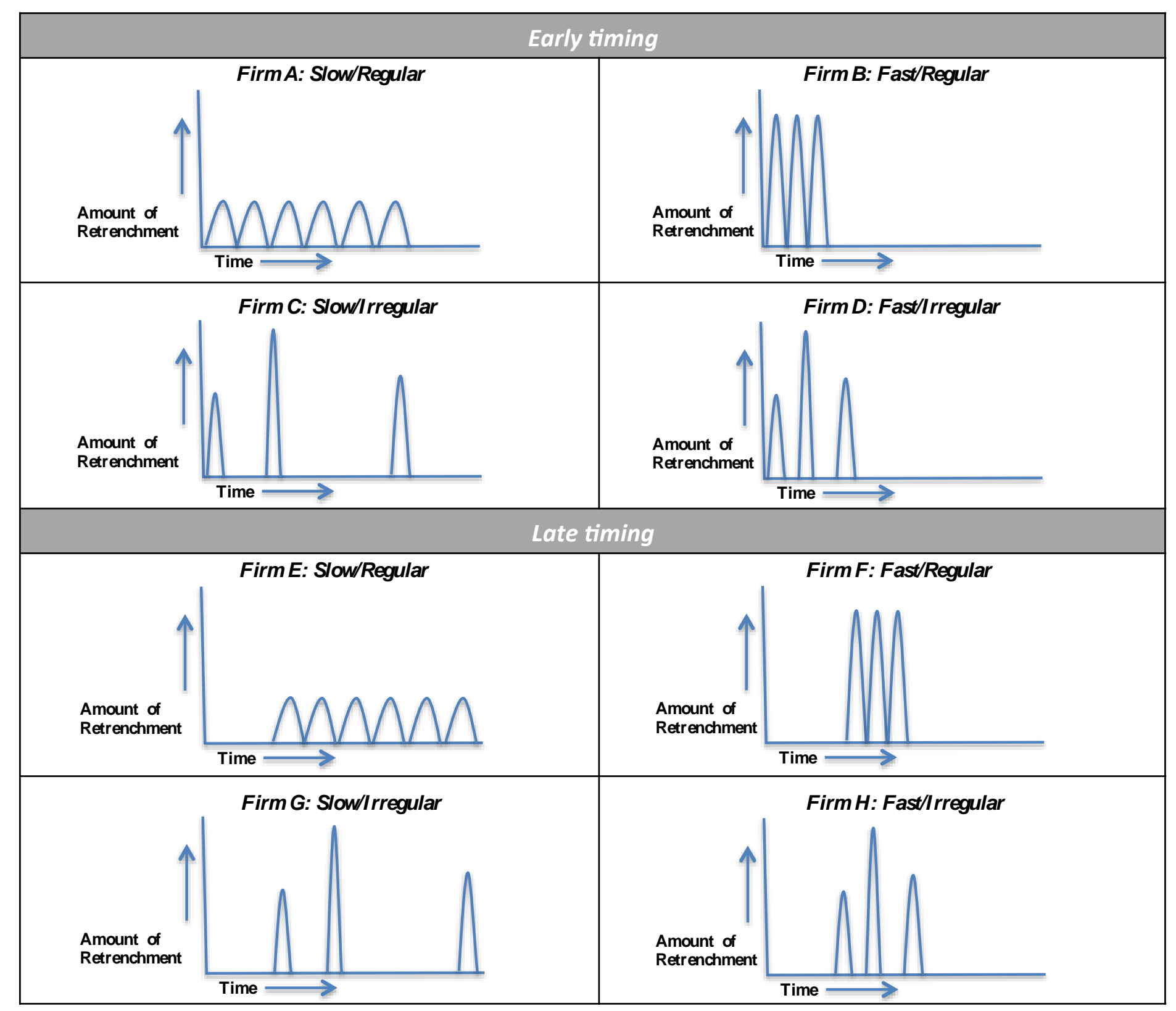

Figure 2. Combinations of timing, speed of retrenchment and rhythm of retrenchment 


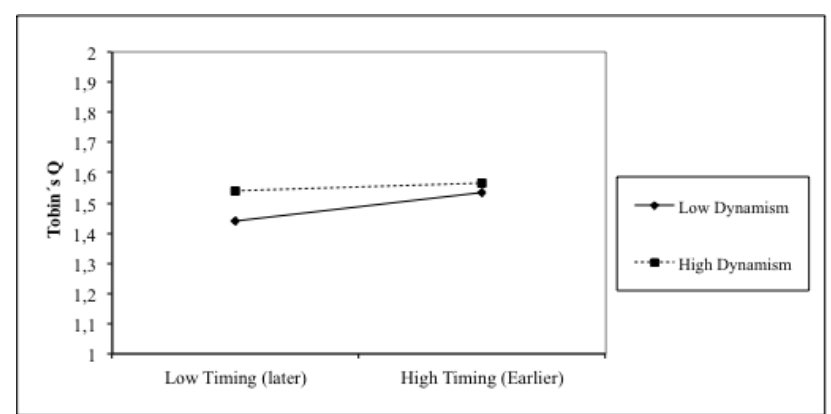

a. Moder ating effects of environmental dynamism on timing of retrenchment and performance

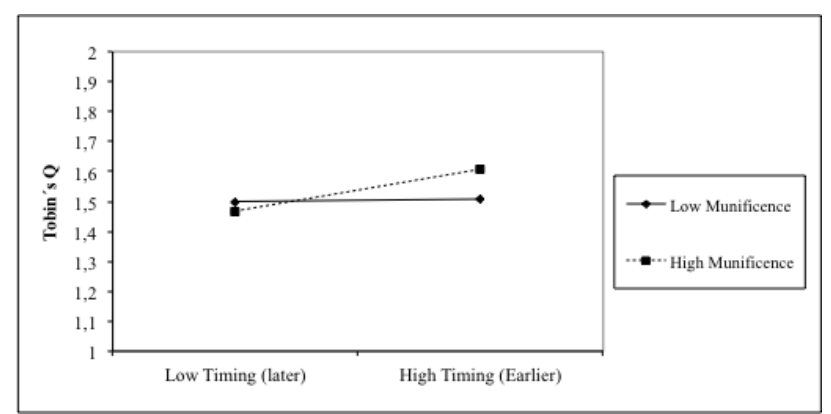

b. Moderating effects of environmental munificence on timing of retrenchment and performance

Figure 3. Moderating effects of timing, environment and firm performance

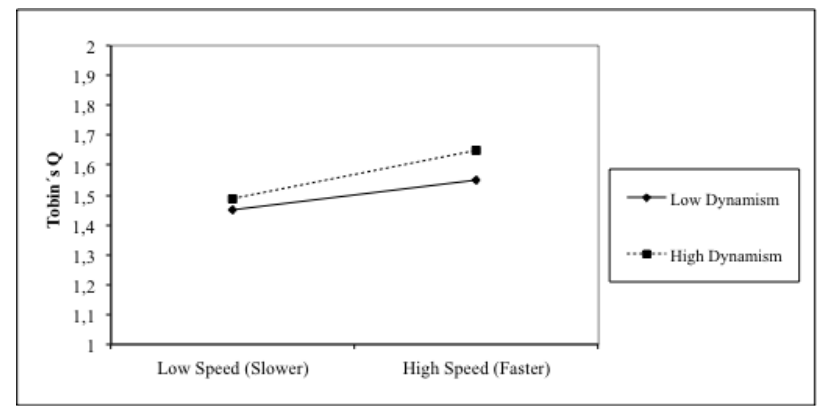

a. Moderating effects of environmental dynamism on

speed of retrenchment and performance

Figure 4. Moderating effects of speed, environment and firm performance

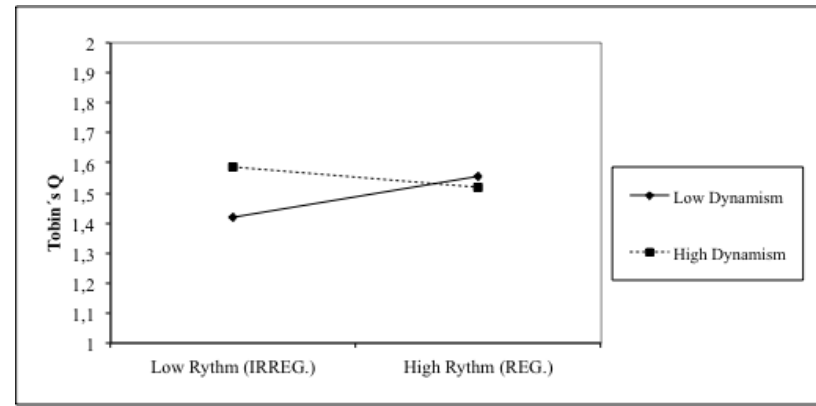

a. Moderating effects of environmental dynamism on rhythm of retrenchment and performance

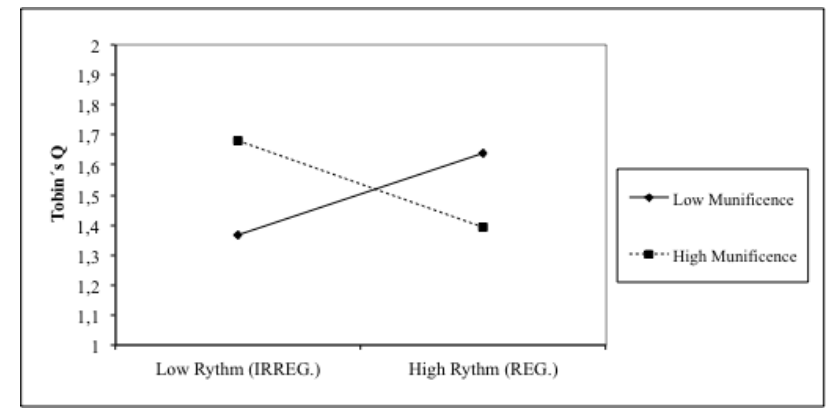

b. Moderating effects of environmental munificence on timing of retrenchment and performance

Figure 5. Moderating effects of rhythm, environment and firm performance 